\title{
Distribution of Catechol O-Methyltransferase Genotypes in a healthy Korean population
}

\author{
Kyung-Sik Yoon, Dong-Seok Yim', Gyo Jun², Hwyoung Hwa Chung', \\ Moon Hee Kim', In-Jin Jang ${ }^{3}$, Beom S Jun', Sang-Goo Shin ${ }^{3}$ \\ Department of Biochemistry Eulji University Medical College, \\ Departments of Pharmacology' and \\ Biochemistry ${ }^{2}$ Gachon Medical School, Green Cross Reference Laboratory",
}

Departments of Pharmacology and Neurology, Seoul National University College of Medicine,

Clinical Trial Center, Seoul National University Hospital, Taejon, Inchon and Seoul, Korea

$=$ 국문초록 $=$

정상 한국인에서 Catechol O-methyltransferase 유전형의 분포

윤경식, 임동석 ${ }^{1}$, 전 교 $^{2}$, 정형화 ${ }^{3}$, 김문희 ${ }^{4}$, 장인진 ${ }^{3}$, 전범석 ${ }^{5}$, 신상구 ${ }^{3}$

올지의대 생화학교실, 가천의대 약리학과', 생화학과', 녹십자임상검사센터', 서울의대 약리학교실 ${ }^{3}$, 신경과학교실

배경 및 연구방법 : Catechol O-methyltransferase(COMT)는 교감신경계 작용에 있어 주요 효소중의 하나 이며 근래에는 각종 정신질환 또는 유방암 등과의 연관성 여부로 주목 받고 있다. 정상 한국인에서 COMT 유전형의 분포를 알기 위해 저자들은 PCR 법을 이용하여 254 명의 유전자형을 진단하였고 그 결과를 타인 종에서의 수치와 비교하였다.

연구결과 : 254 명의 한국인에서 $53 \%$ 는 homozygotic Val158 type(COMT $\left.{ }^{\mathrm{H}} \mathrm{COMT}^{\mathrm{H}}\right), 37$ 는 mixed type ( $\left.\mathrm{COMT}^{\mathrm{H}}{ }^{\mathrm{COMT}} \mathrm{L}\right), 10 \%$ 는 homozygotic Met158 type(COMT ${ }^{\mathrm{L}} \mathrm{COMT}^{\mathrm{L}}$ )으로 판단되었다. 이러한 구성비는 일 본인의 것과 매우 유사하였으며 백인종을 대상으로 한 보고들과 비교해 볼 때 활성도가 낮은 대립유전자 $\left(\mathrm{COMT}^{\mathrm{L}}\right)$ 의 분율이 의미있게 낮은 것으로 나타났다 $(\mathrm{p}<0.001)$.

결 론:본 연구 결과는 향후 한국인을 대상으로 한 각종 질환과 COMT 유전형과의 연관성을 추구하는 연구롤 위한 기본적인 정보가 될 것이다.

\section{Introduction}

Catechol O-methyltransferase (COMT), the ubiquitous enzyme with its genetic locus on the short arm of chromosome 22, metabolizes some en dogenous catecholamines like epinephrine, norepi nephrine etc. As COMT is one of the major en zymes involved in the catecholaminergic system

\footnotetext{
교신저자 : Dong-Seok Yim

소 속: Department of Pharmacology, Gachon Medical School, 13th Floor Ghil Hospital Emergency Center

주 소: 1198 Kuwol-Dong Namdong-Gu Inchon Korea (ㅇ) 405-760

전 화 : +82-32-460-2152 FAX : +82-32-460-3824 E-mail : yimds@gachon.ac.kr
} 
its possible influence on human behavior or psychiatric illness have been investigated ${ }^{1-4)}$. The report of allelic deletion of COMT in patients with the congenital anomaly named Velo-Cardio-Facial syndrome (VCFS) which commonly accompanies schizophrenia, attention deficiency hyperactivity disorder (ADHD) or bipolar disorder led to the researches to find out the relationship of these psychiatric diseases with $\mathrm{COMT}^{5-6}$.

COMT has also been focused on because of its role in the metabolic elimination of levodopa, the antiparkinsonian drug. Currently marketed COMT inhibitor like tolcapone is used to reduce symptomatic fluctuation and on-off phenomenon in levodopa therapy. Since COMT has long been known to exist as a polymorphic enzyme from population studies on its phenotype ${ }^{7-9)}$, the effect of its inhibitor would show corresponding interindividual variation.

Another topic on COMT under current investigation is its role in breast cancer via catechol-estrogen elimination. Oxidative metabolites of estrogen like 16-alpha-hydroxyestrone, estrogen catechol, and estrogen quinone may give genetic damage ${ }^{10-11)}$ and the subjects COMT activity to eliminate these metabolites might be related to cumulative genetic damage ${ }^{(2)}$. Therefore, the knowledge about the distribution of COMT activity and its genotype in an ethnic group will provide the basic information needed for COMT inhibitor therapy or allelic association study of some neurologic or psychiatric diseases.

Recently, the genetic locus determining the enzy. matic activity of COMT was discovered ${ }^{(3)}$. It is reported that valine found at the 158th amino acid of COMT with high enzyme activity is replaced by methionine in COMT with low enzyme activity. Nowadays, genotype screening in a large popula- tion has become possible by polymerase chain reaction. Hence, researches on the relationship of COMT genotype with various diseases like breast cancer, parkinsonism and some psychoses are done with this method ${ }^{14-17)}$. To evaluate the genotypic characteristics of COMT in healthy Korean people, that will present a basic information for further disease-related COMT research in Koreans and other Asian population, the authors performed population study for genotype distribution of COMT in a healthy Korean people.

\section{Materials \& Methods}

\section{Subjects}

Two hundred and fifty four unrelated Korean adults undergoing health screening in Seoul National University Hospital gave written informed consent to the genotyping study under the same IRB's approval. They were 191 men and 63 women aged 21 to 58 years (mean 34, S.D. 6.5 years) and were devoid of any specific health problems with normal AST and ALT values. Genomic DNA was extracted from peripheral blood leukocytes using kits of Takara Co(Dr Gentle, Tokyo, Japan).

\section{COMT Genotyping}

The Val158Met polymorphism of HSCOMT 2 gene (Guanine Adenine exchange in position 1947, Gene bank accession number z26491) was tested by using the oligonucleotide primer TCGTG GACGCCGTGATTCAGG and AGGTCTGACAACGGGTCAGGC(Bioneer : Seoul, Korea) described by Li et al. 18). The PCR product of $217 \mathrm{bp}$ was digested by the restriction enzyme Nla III 


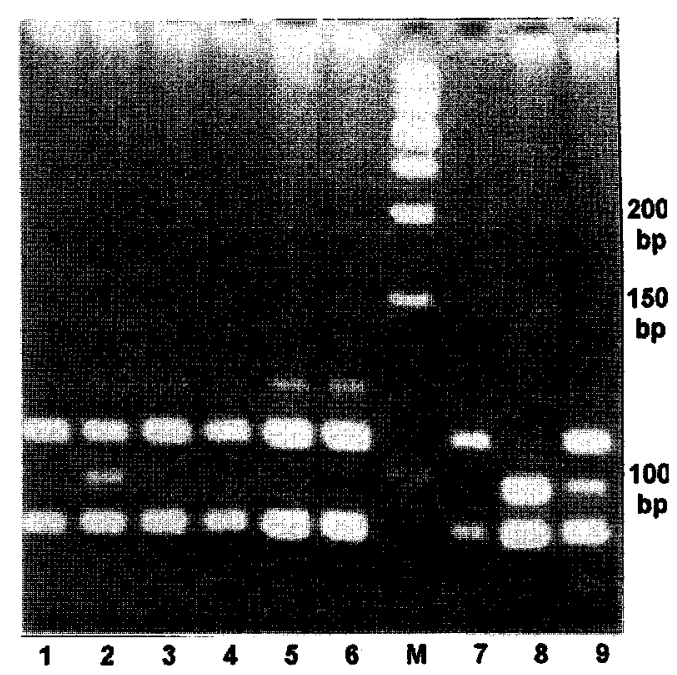

Fig. 1. RFLP analysis of COMT codon 158 polymorphism.

-The lanes numbered $1,3,4,5,6$, and 7 show COMTH $\mathrm{COMT}^{\mathrm{H}}$ genotype.

-The lanes numbered 2 and 9 show COMT "COMT' ${ }^{\mathrm{L}}$ genotype.

-The lane numbered 8 show COMTLCOMT ${ }^{\mathrm{L}}$ genotype.

(New England Biolabs : Beverly, MA, USA). Digestion for 3 hours at $37^{\circ} \mathrm{C}$ gave the fragments of 114,83 , and $20 \mathrm{bp}$ in high activity genome (coding Valine) and $96,83,20$, and 18 bp in low activity genome (coding Methionine). We performed electrophoresis at $100 \mathrm{~V}$ for 35 minutes with $3 \%$ Metaphor agarose gel(FMC, Maine, USA) containing
$0.5 \mathrm{~g} / \mathrm{ml}$ ethidium bromide. The smaller fragments like $18 \mathrm{bp}$ and $20 \mathrm{bp}$ were not seen by electrophoresis. Genotype determination relied on the existence of 114 or $96 \mathrm{bp}$ fragments(Fig. 1).

\section{Statistical Analysis}

The influence of sex and race (in comparison with other reports) on genotypic distribution was assessed by the $\chi$-square test.

\section{Results}

The COMT genotype in 254 Koreans consisted of $53 \%$ of homozygotic Val158 type (COMT ${ }^{\mathrm{H}}$ COMT ${ }^{\mathrm{H}}$ ), $37 \%$ of mixed type (COMT ${ }^{\mathrm{H}} \mathrm{COMT}^{\mathrm{L}}$ ) and $10 \%$ of homozygotic Met158 type (COMT ${ }^{\mathrm{L}} \mathrm{COMT}^{\mathrm{L}}$ ). The allele frequencies calculated from those ratios were $71 \%$ for $\mathrm{COMT}^{\mathrm{H}}$ and $29 \%$ for $\mathrm{COMT}^{\mathrm{L}}$. Sex was not related to the allele frequency of the subjects (Table 1). The allele frequencies in other ethnic groups are shown in Table 2. The data in the ethnic groups other than Koreans were from the normal control groups for each of the genotyping researches to find the relationship between COMT genotype and psychiatric diseases. The distribution of COMT genotype in Koreans was significantly different from

Table 1. COMT genotype in healthy, unrelated Korean population

\begin{tabular}{ccccccc}
\hline & \multicolumn{3}{c}{ Genotype Count : } & \multicolumn{2}{c}{ Allele Frequency } \\
& No. (Frequency) & & \\
\hline & No. & COMT $^{\mathrm{H}}$ & COMT & COMT $^{\mathrm{L}}$ & \multirow{2}{*}{ COMT $^{\mathrm{H}}$} & COMT $^{\mathrm{L}}$ \\
& COMT $^{\mathrm{H}}$ & COMT $^{\mathrm{L}}$ & COMT $^{\mathrm{L}}$ & & $29 \%$ \\
\hline \hline Male & 191 & $101(53 \%)$ & $70(37 \%)$ & $20(10 \%)$ & $71 \%$ & $28 \%$ \\
\hline Female & 63 & $34(54 \%)$ & $23(36.5 \%)$ & $6(9.5 \%)$ & $72 \%$ & $29 \%$ \\
\hline Total & 254 & $135(53 \%)$ & $93(37 \%)$ & $26(10 \%)$ & $71 \%$ & $29 \%$ \\
\hline
\end{tabular}


- K. S. Yoon, et al : COMT genotype in Korean population -

Table 2. Frequency profile of high and low activity alleles of COMT in Korean population and those in other ethnic groups. Allele frequency of Koreans is significantly different from those of caucasians

\begin{tabular}{|c|c|c|c|c|c|c|}
\hline \multirow[t]{2}{*}{$\begin{array}{c}\text { Ethnic group } \\
\text { (Reference No.) }\end{array}$} & \multirow[b]{2}{*}{ No. } & & $\begin{array}{l}\text { notype Cou } \\
\text { (Frequenc }\end{array}$ & & \multicolumn{2}{|c|}{ Allele Frequency } \\
\hline & & $\begin{array}{l}\mathrm{COMT}^{\mathrm{H}} \\
\mathrm{COMT}^{\mathrm{H}}\end{array}$ & $\begin{array}{l}\text { COMT }^{\mathrm{H}} \\
\text { COMT }^{\mathrm{L}}\end{array}$ & $\begin{array}{l}\mathrm{COMT}^{\mathrm{L}} \\
\mathrm{COMT}^{\mathrm{L}}\end{array}$ & $\mathrm{COMT}^{\mathrm{H}}$ & $\mathrm{COMT}^{\mathrm{L}}$ \\
\hline Korean & 254 & $135(53 \%)$ & $93(37 \%)$ & $26(10 \%)$ & $71 \%$ & $29 \%$ \\
\hline Han Chinese (18) & 98 & $66(67 \%)$ & $29(30 \%)$ & $3(3 \%)$ & $82 \%$ & $18 \% *$ \\
\hline Japanese (15) & 153 & $74(48 \%)$ & $70(46 \%)$ & $9(6 \%)$ & $71 \%$ & $29 \%$ \\
\hline Caucasian(USA) (14) & 78 & $20(26 \%)$ & $33(42 \%)$ & $25(32 \%)$ & $47 \%$ & $53 \% *$ \\
\hline Spanish (19) & 113 & $35(31 \%)$ & $57(50 \%)$ & $21(19 \%)$ & $57 \%$ & $43 \%^{*}$ \\
\hline Caucasian(Eur) (16) & 121 & $29(24 \%)$ & $62(51 \%)$ & $30(25 \%)$ & $49.5 \%$ & $50.4 \% *$ \\
\hline
\end{tabular}

* : Significant difference of allele frequency compared with Koreans. All of the data except for the data in Koreans are from normal control groups of research articles in references.

those of Caucasians ${ }^{14,16,19\}}$. Caucasians had greater allele frequency for $\mathrm{COMT}^{\mathrm{L}}$ genotype than those in Asian peoples.

\section{Discussion}

Ethnic difference of some enzymes involved in the drug metabolism has been extensively searched so far. Screening and counting of the frequency of outliers with remarkably high or low metabolic activity has been a traditional way in population studies on the phenotype. But the enzymes like thiopurine methyltransferase (TPMT) or COMT do not show well discernible phenotype distribution, but rather widely overlapping enzyme activities in any ethnic groups studied ${ }^{7,9)}$. Genotyping of such enzymes instead of phenotyping is a simple way of evaluation of the frequency distribution. Though there are some silent mutations reported ${ }^{19}$, only a change in the 158th amino acid (Valine or Methionine) of COMT is believed to explain the difference in enzyme activity. Such simplicity of mutation and the advanced molecular laboratory methods made the genotyping for large population and its interpretation performed by many groups of researchers.

Though the data referred for comparison were not from the studies originally designed to evaluate the interethnic differences in normal population, easily discernible interethnic differences were observed. The allelic frequency of Met158 (low activity) type in Koreans (29\%) was identical to that of Japanese (29\%) and greater than that of Chinese ( $18 \%, \mathrm{p}<0.001$, Table 2). Considering the fact that all subjects of the Chinese data were indigenous to southwestern China (Sichuan province), further study seems necessary to discuss interethnic differences between these three Asian populations. The $\chi$-square test showed that Asian populations including Koreans have significantly lower Met158 genotype frequency than Caucasian groups $(p<0.001)$. As COMT genotype is known 
to be inherited regardless of sex and the genotype does not change by aging, the reliability of the present comparison can be regarded as considerable. The clinical implication of this racial difference in genotype needs to be determined, but given the fact that COMT is a major enzyme in the catecholamine system, one may assess possible racial difference in the effect of some CNS drugs. In the epidemiologic research to find the implication of COMT genotype on breast cancer, its frequency in normal population would also be one of fundamental references.

Background \& Method: Catechol O-methyltransferase (COMT) is one of the key enzymes in the sympathetic nervous system and have been studied for its role in psychiatric, neurologic diseases and estrogen-related cancer. For the evaluation of COMT genotype profile in normal healthy Koreans, authors performed population study by the PCR-based RFLP method.

Result : COMT genotypes in 254 Korean population consisted of $53 \%$ of homozygotic Val158 type(COMT $\left.{ }^{\mathrm{H}} \mathrm{COMT}^{\mathrm{H}}\right), 37 \%$ of mixed type $\left(\mathrm{COMT}^{\mathrm{H}} \mathrm{COMT}^{\mathrm{L}}\right.$ ) and $10 \%$ of homozygotic Met158 type $\left(\mathrm{COMT}^{\mathrm{L}} \mathrm{COMT}^{\mathrm{L}}\right)$. These results were very similar to those of Japanese, while a smaller proportion of low activity allele $(p<0.001)$ was noted in Koreans when compared with Caucasians.

Conclusion : In the researches to find the implication of COMT genotype on many diseases in Korean people, the current result will be used as a fundamental data.

Key words : COMT $\cdot$ Genotype $\cdot$ Korean $\cdot$ Population.

\section{References}

1. Puzynski S, Bidzinski A, Mrozek S, Zaluska M. Studies on biogenic amine metabolizing enzymes (DBH, COMT, MAO) and pathogenesis of affective illness II. Erythrocyte catechol $-O^{-}$ methyltransferase activity in endogenous depression. Acta Psychiatr Scand 1983;67:96100

2. Karege F, Bovier P, Gaillard IM, Tissot R. The decrease of erythrocyte catechol O-methyltransferase activity in depressed patients and its diagnostic significance. Acta Psychiatr Scand 1987; 76:303-8

3. Kuperman S, Kramer J, Loney J. Enzyme activity and behavior in hyperactive children grown up. Biol Psychiatry 1988;24:375-83

4. Baron M, Gruen R, Levitt M, Hunter C, Asnis L. Erythrocyte catechol O-methyltransferase activity in schizophrenia:analysis of family data. Am J Psychiatry 1984; 141:29-32

5. Shprintzen RJ, Goldberg RB, Lewin ML, Sidoti EJ, Berkman MD, Argamaso RV, Young D. New syndrome involving cleft palate, cardiac anomalies, typical facies, and learning disabilities. Cleft Palate J 1978; 15:56-62

6. Lasseter K, Pulver AE, Wolyniec PS. Follow-up report of potential linkage for schizophrenia on chromosome 22q: part3. Am J Med Genet $1995 ; 60: 172-3$

7. Weinshilbaum RM, Raymond FA. Inheritance of low erythrocyte catechol-O-methyltransferase activity in man. Am J Hum Genet 1997;29: 125-35

8. Weinshilbaum RM, Sladek S, Klumpp S. Human erythrocyte thiol methyltransferase:radioche- 
- K. S. Yoon, et al : COMT genotype in Korean population -

mical microassay and biochemical properties.

Clin Chim Acta 1979;97:58-71

9. Mcleod HL, Fang L, Luo X, Scott EP, Evans WE. Ethnic differences in erythrocyte COMT activity in black and white Americans. $J$ Pharmacol Exp Ther 1994;270:26-9

10. Davis DL, Bradlow HL, Wolff M, Woodruff T, Hoel DG, Anton-Culver H. Medical hypothesis:xenoestrogens as preventable causes of breast cancer. Environ Health Perspect 1993; 101:372-7

11. Yager JD, Liehr JG. Molecular mechanisms of estrogen carcinogenesis. Ann Rev Pharmacol Toxicol 1996; 36:203-32

12. Lavigne JA, Helzlsouer KJ, Huang HY, Strickland PT, Bell DA, Selmin O, Watson MA, Hoffman S, Comstock GW, Yager JD. An association between the allele coding for a low activity variant of catechol O-methyltransferase and the risk for breast cancer. Cancer Res 1997;57:5493-7

13. Lotta T, Vidgren J, Tilgmann C, Ulmanen I, Melen K, Julkunen I, Taskinen J. Kinetics of human soluble and membrane-bound catechol O-methyltransferase: a revised mechanism and description of the thermolabile variant of the enzyme. Biochemistry 1995; 34:420210

14. Daniels JK, Williams NM, Williams J, Jones LA, Cardno AG, Murphy KC, Spurlock G, Riley B, Scambler P, Asherson P, MoGuffin P, Owen MJ. No evidence for allelic association between schizophrenia and a polymorphism determin- ing high or low catechol O-methyltransferase activity. Am J Psychiatry 1996; 153:268-70

15. Kunugi H, Vallada HP, Sham PC, Hoda F, Arranz MJ, Li T, Nanko S, Murray RM, McGuffin P, Owen M, Gill M, Collier DA. Catechol O-methyltransferase polymorphisms and schizophrenia: a transmission disequilibrium study in multiply affected families. Psychiatr Genetics 1997a;97-101

16. Kunugi H, Vallada HP, Hoda F, Kirov G, Gill M, Aitchison KJ, Ball D, Arranz MJ, Murray RM, Collier DA. No evidence for an association of affective disorders with high-or low-activity allele of catechol O-methyltransferase gene. Biol Psychiatry 1997b;42:282-5

17. Karayiorgou M, Altemus M, Galke BL, Goldman D, Murphy DL, Ott J, Gogos JA. Genotype determining low catechol $O$-methyltransferase activity as a risk factor for obssessive-compulsive disorder. Proc Natl Acad Sci USA 1997; 94: $4572-5$

18. Li T, Vallada H, Curtis D, Arranz M, Xu K, Cai G, Deng H, Liu J, Murray R, Liu X, Collier DA. Catechol O-methyltransferase Val153Met polymorphism: frequency analysis in Han Chinese subjects and allelic association of the low activity allele with bipolar affective disorder. Pharmacogenetics 1997. 7:349-53

19. Gutierrez B, Bertranpetit J, Guillamat R, Valles V, Arranz MJ, Kerwin R, Fananas L. Association analysis of the catechol-O-methyltransferase gene and bipolar affective disorder. Am J Psychiatry 1997; 154: 113-5 